\title{
Effect of Coir Fiber and Inorganic Filler Hybridization on Innegra Fiber Reinforced Epoxy Polymer Composites: Physical and Mechanical Properties
}

\section{H M Kavya}

Dayananda Sagar Institutions

\section{Saravana Bavan}

Dayananda Sagar Institutions

\section{B Yogesha}

Malnad College of Engineering

\section{Sanjay Mavinkere Rangappa ( $\sim$ mcemrs@gmail.com )}

King Mongkut's University of Technology North Bangkok https://orcid.org/0000-0001-8745-9532

\section{Suchart Siengchin}

King Mongkut's Institute of Technology North Bangkok: King Mongkut's University of Technology North Bangkok

\section{Sergey Gorbatyuk}

NUST: National University of Sciences and Technology

\section{Research Article}

Keywords: Titanium Carbide (TiC), differential scanning calorimeter (DSC), scanning electron microscope (SEM), thermogravimetric analysis (TGA)

Posted Date: April 19th, 2021

DOI: https://doi.org/10.21203/rs.3.rs-403910/v1

License: (a) This work is licensed under a Creative Commons Attribution 4.0 International License. Read Full License

Version of Record: A version of this preprint was published at Cellulose on August 19th, 2021. See the published version at https://doi.org/10.1007/s10570-021-04140-x. 


\section{Abstract}

The present investigation is concentrated on the results of different fillers over the physical, mechanical, and thermal characteristics of the epoxy polymer. These epoxy hybrid composites were produced using mechanical-stirring assisted wet layup method with coir micro-particles, fly ash, Titanium Carbide (TiC) nanoparticles, and Innegra fabrics contains simultaneous considering mechanical stirring with a stirring rod. The tensile, flexural, and inter-laminar shear characteristics of fabricated epoxy hybrid composites were determined using a universal testing machine. After the reinforcement of fly ash and TiC nanoparticles offers the most remarkable improvement in tensile, flexural, and impact strength, about $2.84,1.65$, and 9.19 times compared with pure epoxy polymer. The differential scanning calorimeter (DSC) and thermogravimetric analysis (TGA) showed the epoxy hybrid composites' enhanced thermal stability. The homogeneity of fillers dispersion in the epoxy polymer was observed from a scanning electron microscope (SEM). Keywords: Contact angle; Fly ash; Inter-laminar shear strength; Innegra Fabric; Tensile Strength; TiC nanoparticle

\section{Introduction}

The epoxy-based resins are broadly utilized in polymer laminates, automobiles, aerospace, adhesives, paints fabrication, surface coating methodology, and other engineering materials (May and Tanaka, 1973; Rs, 1979). The performance of epoxy composites in sectors is because of their higher corrosion and chemical resistance, greater mechanical and thermal characteristics, lower shrinkage(Adams and Gannon, 1986). Epoxy composites can study in specific environmental situations. The cured epoxy polymer exhibited a 3D (three-dimensional) extremely cross-linked chain scheme. The characteristics of epoxy polymers are strained in different applications because of a higher range of cross-linking density which is influenced by intrinsic brittle behavior of components and lower toughness. Various investigations have been performed to enhance the toughness and other characteristics like thermal stability, dynamic mechanical and crack resistance of epoxy polymer by adding different kinds and quantities of nanoparticles in a polymer (Duraibabu et al., 2014). The breaking and uniform dispersion of nanoclusters inside the polymer are two primary issues for nanolaminates fabrication (Sun et al., 2015). Dispersion and cluster size of nanoparticles in polymer resin shows the confident development in pure polymer's fundamental characteristics with stronger interfacial bonding within the molecular networks and fillers (Radoman et al., 2014; Bal, 2010). The particle accumulation trend because of non-uniform dispersion and van der Waals forces in epoxy polymer has strengthened investigators for deciding the excellent processing methods to lower or decrease the accumulated filler size and provide its homogeneous distribution. Many ways are already in the tendency for polymer nanolaminates fabrication from shear comprising using manual stirring, melt mixing, solution mixing (Becker et al., 1996; Rong et al., 2001), direct addition with chemical route techniques (Kumar et al., 2017; Kang et al., 2001), acoustic cavitation (Eskin, 2001), ultrasound vibrations (Wang et al., 2001), ultrasonic waves (Kumar et al., 2016; Xu et al., 2004), and ultrasonic irradiation (Xia and Wang, 2003). The acoustic cavitation 
method is an efficient process for distributing nanoparticles in polymer resins (Zunjarrao and Singh, 2016; Halder et al., 2012; Tsekmes et al., 2015).

Tsekmes et al. (2015) have declared that epoxy-based laminates benefit from greater breakdown strength with enhanced thermal stability. Generally, utilization of 60-70 wt.\% of silica microparticles in the epoxy laminate insulators can be observed in the industrial sector. Imai et al. (2006) have signified that the silica particle leads to show the lower coefficient of thermal expansion. Ramanujam et al. (2019) have investigated the corona treatment inaugurated because of water contents on IXEPLAS reinforced epoxy nanolaminates. IXEPLAS is a hydrotalcite component customized with zirconium phosphate. Inorganic ion exchangers such as zirconium phosphate lead to better resistance from oxidation and more significant ion entrapping capability. Thus, it can be suitable in the electrical schemes for enhancing their performance.

One of the considerable interests in epoxy laminate samples is water absorption in humid environmental situations. Nogueira et al. (2001) have signified that moisture in epoxy laminates is present in two dissimilar systems, such as bound water in interaction with hydrogen bonding of the laminate and moisture present in the accessible quantity micro-gaps in the resin. In composites' condition, this principle is profound compared to neat epoxy due to the interface between filler and matrix will act as a possible region for the moisture molecule to cooperate (Zou et al., 2008). This principle may potentially tend to considerable irreversible material modifications like final degradation, plasticization, and swelling of insulating material (Wang et al., 2006). Exposing polymeric samples to hot water is one of the usual techniques to affect the long-term process or accelerated aging of moisture uptake principle (Pitarresi et al., 2018). Ramanujam et al. (2019) have performed moisture absorption investigations with pure epoxy and their respective nanolaminates. They have signified that the percentage of the weight of the pristine epoxy polymer is around $0.5 \%$. The epoxy polymer laminate sample applied in the current investigation has a gain in weight $\%$ of about 0.2 . The pure epoxy polymer has a freer amount applicable in the bulk of the sample for the moisture to penetrate. The fillers reinforcement played as protection for water diffusion in the bulk amount of laminate sample, decreasing the moisture absorption compared to neat epoxy. When the moisture absorption of pure epoxy is higher than two times of moisture absorption in a laminate sample, the current investigation is concentrated more on an epoxy hybrid laminate sample to interpret the influence of water absorption and mechanical characteristics.

Nonetheless, it also has many limitations like thermal stability, softness, and flexural modulus (Wu et al., 2019). Incorporating inorganic particles like carbon-based fillers, calcium carbonate, silica, and calcium sulphate is an efficient technique for enhancing the overall characteristics of polymers (Abdel-Gawad et al., 2018; Yuan et al., 2016; Cui et al., 2017; Khaleghi et al., 2017). Among these fillers, fly ash is a reinforcing agent that can adequately enhance the thermal resistance, impact, and modulus of polymers, owing to their other advantageous properties like chemical corrosion resistance, lower cost, higher mechanical properties, availability, higher mechanical strength, and more necessarily usage of industrialization (Dahalan et al., 2018; Liu and Zhong, 2014). Fly ash is the primary solid waste released from pulverized coal's combusting process in thermal power plants. It is now the most excellent 
individual resource of solid waste management (Ding et al., 2017; Temuujin et al., 2019; Wang et al., 2014). The constituent, surface chemical reaction, and mineralogy of fly ash have essential influences on its utilization (Yao et al., 2015; Hower et al., 2017) like wastewater treatment in the industry, catalyst carriers for the modification of poisonous gases, raw materials for plastics, adsorbent, silica aerogels, soil conditioners in agriculture, and construction materials as admixture (Asl et al., 2018; Asl et al., 2019; Cai et al., 2020). When fly ash is made of adaptable active oxides, it can also be applied as a filler for polymer laminates. It can enhance polymer laminates' thermal and mechanical characteristics, whereas fabrication cost is furthermore decreased.

Furthermore, only a restricted quantity of hydroxyl functional group on the surface of fly ash may affect the poor compatibility between polymer and fly ash. Hence, avoid the movement of mechanical stress used to the laminate and subsequently control the laminates' damage (Civancik-Uslu et al., 2018). To enhance the bonding between organic matrix and fly ash, surface treatment of fly ash is essential. Patil et al. (2016) fabricated an optimized planetary ball milling technique from the Taguchi experimental design to manufacturing nano-sized fly ash. Van der Merweet et al. (2014) observed that the treatment of fly ash with sodium lauryl sulphate tends to no considerable modifications in the chemical constituents, and modified fly ash could be applied as reinforcement in polymers under lower content. Furthermore, previous investigations on the activation of fly ash by mechanical alloying have focussed mainly on the fabrication of nano-sized fly ash (Thongsang et al., 2012; Yuan et al., 2019), which generally lacks a long mechanical alloying period higher consumption of energy (Sundum et al., 2018; Li et al., 2017). An easy and efficient treatment technique would share fly ash utilization in the production of advanced industrial components.

Among the different ceramic nanofillers, the titanium carbide (TiC) nanoparticles are known for their higher thermal stability, larger surface area, superior electrical insulation characteristics, and excellent mechanical characteristics that produce it more prominent an inferior aspirant filler (Mallakpour and Khadem, 2015; Omrani et al., 2009). In the present study, the fly ash and TiC are selected as potential reinforcement. The fly ash and $\mathrm{TiC}$ are well-known for their higher mechanical characteristics and thermal stability. From the literature study, it has been observed that limited investigations have been conducted to manufacture hybrid composite with coir and Innegra fiber incorporated in the epoxy resin with fly ash and TiC. In this study, an experiment has been appointed to fabricate composites combined with Innegra fiber, fly ash, TiC filler comprised with coir fiber in the epoxy polymer. The effect of fly ash and TiC particles incorporation in Coir fiber-Innegra fiber-epoxy composite on morphological, mechanical, and thermal characteristics were measured from tensile, impact, inter-laminar shear strength, flexural, hardness, scanning electron microscope (SEM), differential scanning calorimeter (DSC), and thermogravimetric analysis (TGA) is considered.

\section{Materials And Methods \\ 2.1. Materials}


In the present investigation, synthetic epoxy Epotec YD-535 LV and hardener of Epotec TH-725 were used as polymer matrix and procured from Aditya Birla Chemicals Ltd., Thailand. The coconut fibers purchased from Tongmongkol Coconut fiber, Prachuapkhirikhan, Thailand was applied as reinforcement material for the manufacturing of synthetic epoxy laminate. Two types of inorganic fillers were utilized in this investigation as TiC (10 nm of particle size) was supplied from Zhuzhou Sanyinghe International Trade Co. Ltd., China, and fly ash was collected from industrial chimney, Thermal Power Plant, Chennai applied as another filler reinforcement to the matrix. A novel Innegra fiber has been purchased from Innegra Technologies, South Carolina, United States in the form of woven mat and also applied as a reinforcement material to the synthetic epoxy polymer.

\subsection{Fabrication of synthetic epoxy hybrid composite}

The purchased coconut fibers were cleared up with fresh water to eliminate the dirt particles and dried in sunlight for three days to remove the moisture content. The cleaned coconut fibers were sectioned into small pieces and transferred to the Universal milling machine to produce the micro-fillers from coconut fibers subjected to sieving and separated from a $250 \mu \mathrm{m}$ filter. The synthetic hardener, epoxy polymer, and reinforcement fillers were weighed accurately in different ratios with the help of weighing balance. The details for the fabrication of the epoxy hybrid composite are shown in Table 1. The mechanical stirring was applied to achieve a homogeneous distribution of fillers in the epoxy polymer. The combined mixture was rapidly transferred to the die mold to avoid premature curing and discharge for a slower curing process. The fabricated sample was removed from the die mold and shifted to the furnace for post-curing at $80 \pm 2^{\circ} \mathrm{C}$ to decrease the sample's residual moisture. 
Table 1

Detailed information about the fabrication of coir fiber/ Innegra fiber/ TiC/ fly ash synthetic epoxy hybrid composites

\begin{tabular}{|c|c|c|c|c|c|}
\hline $\begin{array}{l}\text { Hybrid } \\
\text { Composite } \\
\text { type }\end{array}$ & Description & $\begin{array}{l}\text { Coir } \\
\text { micro- } \\
\text { particles }\end{array}$ & $\begin{array}{l}\text { Innegra } \\
\text { fabric }\end{array}$ & $\begin{array}{l}\text { TiC } \\
\text { nanoparticles }\end{array}$ & $\begin{array}{l}\text { Fly } \\
\text { Ash }\end{array}$ \\
\hline PE & $\begin{array}{l}\text { Pure synthetic epoxy (Epotec YD-535 } \\
\text { LV and hardener Epotec TH-725) }\end{array}$ & - & - & - & - \\
\hline \multirow[t]{2}{*}{ CIPE } & \multirow[t]{2}{*}{$\begin{array}{l}\text { Epotec YD-535 LV reinforced with coir } \\
\text { micro-particles, and Innegra fabric }\end{array}$} & \multirow[t]{2}{*}{10 wt.\% } & $\begin{array}{l}3 \\
\text { layers }\end{array}$ & - & - \\
\hline & & & $\begin{array}{l}(116 \\
\left.g / m^{2}\right)\end{array}$ & & \\
\hline \multirow[t]{2}{*}{ CFIPE } & \multirow{2}{*}{$\begin{array}{l}\text { Epotec YD- } 535 \text { LV reinforced with coir } \\
\text { micro-particles, fly ash, and Innegra } \\
\text { fabric }\end{array}$} & \multirow[t]{2}{*}{5 wt.\% } & $\begin{array}{l}3 \\
\text { layers }\end{array}$ & - & $\begin{array}{l}5 \\
\text { wt. } \%\end{array}$ \\
\hline & & & $\begin{array}{l}(116 \\
\left.g / m^{2}\right)\end{array}$ & & \\
\hline \multirow[t]{2}{*}{ CTIPE } & \multirow[t]{2}{*}{$\begin{array}{l}\text { Epotec YD-535 LV reinforced with coir } \\
\text { micro-particles, TiC nanoparticles, and } \\
\text { Innegra fabric }\end{array}$} & \multirow[t]{2}{*}{5 wt.\% } & $\begin{array}{l}3 \\
\text { layers }\end{array}$ & 5 wt. \% & - \\
\hline & & & $\begin{array}{l}(116 \\
\left.g / m^{2}\right)\end{array}$ & & \\
\hline \multirow[t]{2}{*}{ CFTIPE } & \multirow[t]{2}{*}{$\begin{array}{l}\text { Epotec YD-535 LV reinforced with coir } \\
\text { micro-particles, fly ash, TiC } \\
\text { nanoparticles, and Innegra fabric }\end{array}$} & \multirow[t]{2}{*}{4 wt.\% } & $\begin{array}{l}3 \\
\text { layers }\end{array}$ & 3 wt.\% & $\begin{array}{l}3 \\
\text { wt. } \%\end{array}$ \\
\hline & & & $\begin{array}{l}(116 \\
\left.g / m^{2}\right)\end{array}$ & & \\
\hline
\end{tabular}

\subsection{Characterization of fabricated epoxy hybrid composite 2.3.1. Fourier Transform Infra-red (FTIR) spectrum}

FTIR spectra analysis was conducted with the sample comprised in a $\mathrm{KBr}$ (Potassium Bromide) filler from Perkin Elmer Spectrum 2, FTIR spectrometer. The epoxy hybrid composite's wavenumber was ranging between 4000 and $400 \mathrm{~cm}^{-1}$ with a resolution of $1 \mathrm{~cm}^{-1}$ under 32 scans per minute.

\subsubsection{Water absorption capacity}

According to the ASTM D 570 standard, the water absorption capacity was performed for epoxy hybrid laminates. The specimen was dried in a heating furnace for a specific period at $80 \pm 2^{\circ} \mathrm{C}$, and the initial mass of the specimen was determined. The fabricated epoxy hybrid laminates were then immersed in fresh water at $24 \pm 2^{\circ} \mathrm{C}$ for three months. After immersing, specimens were taken out, excess water has been cleaned with a cotton cloth, and the final weight was measured. The variation between the final and initial mass has been determined, and the amount of water absorption has been estimated as per the standard. 


\subsubsection{Contact angle}

The contact angle test experimented in $15 \mathrm{LJ}$ data physics, Optical contact angle (OCA) under $26 \pm 2^{\circ} \mathrm{C}$ and $1 \mu \mathrm{L}$ of deionized water were poured on the surface of epoxy hybrid laminate with the help of a syringe. The left and right contact angles were determined, and for each specimen, the mean value of five parts was recorded as an outcome.

\subsubsection{Mechanical characteristics}

The mechanical characteristics are essential for the utilization of composite materials. The specimens (width $x$ length $\mathrm{x}$ thickness: $15 \mathrm{~mm} \times 100 \mathrm{~mm} \times 3 \mathrm{~mm}$ ) for the tensile experiments were conducted as per the ASTM D 3039 standard. The specimens were fixed on the Cometech Universal Testing Machine and expanded longitudinally at $1 \mathrm{~mm} / \mathrm{min}$ until they break.

Short beam shear and three-point bending experiments were performed in Cometech Universal Testing Machine of $10 \mathrm{kN}$ load cell in three-point flexural loading arrangement. The crosshead speed and preload of $5 \mathrm{~mm} / \mathrm{min}$ and $0.1 \mathrm{MPa}$, respectively, were employed. The inter-laminar shear strength of the laminate was investigated by controlling the thickness to span proportion 4 to 5 according to the ASTM D 2344-16 standard. The smaller span length increases the cracking and shear failure along the horizontal plane between the layers. The flexural modulus and strength of the manufactured epoxy hybrid laminates were measured according to the ASTM D 790 standard with a span to a thickness of 32 . The bending specimen's dimension encompasses a width of $15 \mathrm{~mm}$ and a span length of $80 \mathrm{~mm}$. The flexural strength at the exterior fiber at the center point and the flexural modulus was calculated as per the standard. The Izod impact test of the epoxy hybrid composites was determined from Zwick/ Roell Impact testing machine furnished with an Izod $5.5 \mathrm{~J}$ hammer constructed as per the ASTM D 256 standard and accommodating to the technique based on the standard (un-notched).

The Shore $D$ hardness of the fabricated synthetic epoxy hybrid composites was determined with the indenter-based hardness measurement machine. The indenter was pressured on the sample's surface up to the bottom portion of the indenter is in full strike with the composite. The dial of the hardness indenter signifies the Shore $D$ hardness of the epoxy hybrid composites. The experiments were carried out under ten different composite positions, and mean hardness outcomes were determined. All the experiments were performed under $60 \%$ of relative humidity and $24 \pm 2^{\circ} \mathrm{C}$ of room temperature.

\subsubsection{Fractographic evaluation}

The microstructures were observed from a scanning electron microscope, FEI 450 Quanta, with $15 \mathrm{kV}$ of accelerating voltage to examine how different reinforcements influence a polymer's structure.

\subsubsection{Thermal characteristics}

DSC (Differential scanning calorimeter) graphs from 20 to $300^{\circ} \mathrm{C}$ were reported from Mettler Toledo, DSC $3+/ 700 / 2167$ machine at nitrogen atmosphere under the heating rate of $10^{\circ} \mathrm{C} / \mathrm{min}$. The TGA (thermogravimetric analysis) was performed on Mettler Toledo, TGA 2, TGA/DSC $3+$ HT/1600 machine to 
examine the epoxy hybrid's thermal stability composites. The specimens were heated between 30 and $700^{\circ} \mathrm{C}$ under a nitrogen atmosphere with a heating rate of $15^{\circ} \mathrm{C} / \mathrm{min}$. The mass loss was determined, and residual char content was measured from $600^{\circ} \mathrm{C}$ with the help of DTG (derivative thermograms).

\section{Results And Discussion}

\subsection{Effect on FTIR spectra}

Figure 1 exhibits the FTIR spectrum of pure epoxy polymer and their respective laminates based on the filler and Innegra fabric reinforcement to examine the effect of inorganic fillers and epoxy functional groups. The pure epoxy polymer shows a clear carboxyl peak at $1654 \mathrm{~cm}^{-1}$ existing to $\mathrm{C}-\mathrm{O}$ stretch functional groups. Other peaks at 1490 and $1596 \mathrm{~cm}^{-1}$ are ascribed to a benzene ring. Whereas two constrain intensity peaks between 930 and $770 \mathrm{~cm}^{-1}$ and the peak at $1226 \mathrm{~cm}^{-1}$ relates to the asymmetric and symmetric stretching peaks of R-O-R, respectively (Niu et al., 2014; Niu et al., 2021). The effect of various inorganic filler constituents on the epoxy polymer's molecular chain has primarily followed the peak at $630 \mathrm{~cm}^{-1}$. The vibration kinds in this region are obscured and imbricating, and the features were terrible. The FTIR spectrum signifies that epoxy polymer and laminate specimens exhibit the evident characteristics peaks of epoxy polymer. The chemical scheme of epoxy polymer is not considerably modified with the incorporation of different fillers. In the FTIR spectrum of CFIPE and CFTIPE laminates, two other characteristic peaks can be examined at 1430 and $880 \mathrm{~cm}^{-1}$ that can be assigned to the asymmetric and out of plane ben vibration the CO32-functional groups in fly ash (Jena and Sahoo, 2019). Hence, it can be proved that calcium carbonate is the principal constituent of fly ash. Hydrogen bonds produce efficiently between the hydroxyl regions. When this happens, the hydroxyl stretch vibration shows red movement in the infra-red spectra. The production of hydrogen bonds between the hydroxyl functional groups affects this principle known as the effect of hydrogen bonding (Finch, 1970).

From the infra-red spectrum, the hydroxyl stretch vibrations of CIPE, CFIPE, CTIPE, and CFTIPE composites were $3430,3431,3440$, and $3445 \mathrm{~cm}^{-1}$, respectively. As shown in CIPE, CFIPE, CTIPE, and CFTIPE, the incorporation of fillers concluded in producing more hydrogen bonds between coir fiber, epoxy, fly ash, TiC, and Innegra fabric, signifying an increment in crosslinks between various constituents (Zhang et al., 2018). This outcome is the production of a close compact system; hence, these laminates' enhanced mechanical characteristics can be described (Deshmukh et al., 2021). The hydroxyl-stretch vibration of the CISE composite was lower than that of the CFIPE, CTIPE, and CFTIPE due to inorganic fillers' presence (Wu et al., 2020). Further, it can produce a new hydrogen bond with the polymer as an essential constituent of fly ash, TiC, and Innegra fabric may also offer some hydroxyl functional groups to create hydrogen bonds with the polymer. Furthermore, the crystallinity index more actively influenced the mechanical characteristics than the hydroxyl-stretch vibration, signifying that crystallinity was the primary parameter that impacted the polymer composites' mechanical aspects (Ji et al., 2021; Sun et al., 2019). 


\subsection{Effect on physical properties}

Figure 2 (a) exhibits that after 90 days, water absorption attains 2.48\% (CTIPE), 2.01 (PE), 1.83\% (CFIPE), $1.44 \%$ (CIPE), and $1.42 \%$ (CFTIPE). The CTIPE composite consumed more water while comparing with other combinations due to the greater pore structure. A similar outcome has been observed by Ajdary et al. (2020), considered that greater pores tend to higher absorption water under capillary action. Furthermore, the particular kind of filler did not noticeably modify the quantity of water consumed. This can be assigned to the principle that all the specimens were porous and consume more water under the capillary action. However, polymer reinforced most hydrophilic functional groups, and CFTIPE, CIPE, and CFIPE are more hydrophobic than polymers (Deshmukh et al., 2021; Ajdary et al., 2019; Zhang et al., 2017). The particles were uniformly distributed in the laminates, improving their durability with water. The hydroxyl functional groups of CIPE and CFTIPE influenced them to combine strongly with the laminate, resulting in this marginally decreasing the quantity of water consumed from the CIPE and CFTIPE laminates.

The water contact angle is the important factor that signifies the water's wettability on the surface of the fabricated laminate. Figure 2 (b) presents the water contact angle after $5 \mathrm{~min}$; the outcomes are PE $\left(81.4^{\circ}\right)>\operatorname{CFIPE}\left(76.63^{\circ}\right)>\operatorname{CFTIPE}\left(74.73^{\circ}\right)>\operatorname{CIPE}\left(70.9^{\circ}\right)>\operatorname{CTIPE}\left(69.83^{\circ}\right)$. In 5 min, the PE, CFIPE, CFTIPE, and CIPE was nearing the hydrophobic condition. The CTIPE laminate was previously hydrophilic. The fillers enhanced the water-resistance and can almost attain the influence of waterproofing TiC and fly ash (Sun et al., 2019). The surface energy of the laminates improved with the incorporation of fillers; furthermore, the appearance of certain hydrophilic inorganic components in epoxy polymer reduced the surface energy (Wu et al., 2020). In this context, the dense architecture affected by the increment of crosslinking and the capillary action of various diameters of pores also outcome in distinct water contact angles (Deshmukh et al., 2021; Ajdary et al., 2020). Hence, the water contact angle improved to fluctuating degrees upon the reinforcement of coir fiber, TiC filler, and fly ash.

\subsection{Effect on mechanical properties}

\subsubsection{Tensile properties}

Figure 3 (a) presents the stress-strain graphs of the epoxy hybrid composites reinforced with different fillers. The influence of other filler addition on the tensile strength and modulus of epoxy hybrid composites were measured and presented in Fig. 3 (b). Figure 3 (b) exhibits that the tensile modulus and strength of CIPE, CFIPE, CTIPE, and CFTIPE composite improved by $2.89,1.71,2.52$, and 2.84 times respectively. The strength of the epoxy hybrid composites based on the dispersion of fillers in the polymer and bonding between the matrix and particles. The uniform distribution of particles in complete polymer acted as a specific character to enhance the tensile characteristics of laminate. The testing process efficiently damages the cluster size of filler and disperses the filler uniformly incomplete polymer. CFIPE laminate presented lower tensile attributes because of the improvement in cluster size and density of the filler. The tensile characteristics of CTIPE and CFTIPE composite showed reduced when compared with 
CIPE composite. The reduction in tensile characteristics under this reinforcement can be explained by an incrementing susceptibility of accumulation, which tends to lower energy dissipation in the scheme under the deformation of viscoelasticity. It was observed that with the increment in weight and accumulation size, the movement of molecule and chains become simple, which leads to a reduction in tensile characteristics. The greater cluster size of filler also decreases the bonding of filler-polymer and offers a more straightforward method to increase the initial damage during the tensile load.

Other investigators have observed similar results that the improvement in strength is assigned to the principle that the Zirconia filler has much better stability than the epoxy polymer and also to the stronger bonding between the polymer and filler that allows the suitable load dispersion in hybrid laminate regions (Ma et al., 2018; Kumar et al., 2021). The decrement in strength is ascribed to the appearance of the higher amount of clusters. Furthermore, homogeneous cluster-free distribution and strong bond interaction of optimum fillers reinforcement with polymer permits part of the load transfer, leading to the epoxy composites' considerable tensile characteristics (Haldar et al., 2012).

\subsubsection{Tensile fracture}

The SEM micrograph of the tensile experimented samples observed in Fig. 4. The epoxy polymer sample's fracture microstructure examines the crack and brittle behavior, as observed from previous published literature (Mohit et al., 2021). Figure 4 (a) shows the CIPE sample affirms the portion of inadequate filler dispersed from the epoxy polymer and the matrix fragmenting. The extensive matrix damage and failure of a filler-matrix interface are also apparent. SEM micrographs of CFIPE signifies the portion of Innegra fiber deceived and constrained micro-cracks (Fig. 4b). The addition of fly ash decreases the bulging of Innegra fiber bundles and attempts of damage at an initial point of reinforcing by prohibiting the crack generation. The SEM micrograph of CTIPE shows the isolated epoxy/ titanium carbide/ coir fiber cluster and the Innegra fibers' forecast to the outer part. The debonding of the Innegra fiber-epoxy/titanium carbide/ coir fiber is found in certain portions because of the failure of interfacial bonding (Fig. 4c).

Furthermore, compared with the neat epoxy and CIPE, in this condition, almost all the Innegra fibers imply to be coated with the epoxy/ titanium carbide/ coir fiber even after the disintegration. This signifies a better bonding between the Innegra fabric and epoxy/ titanium carbide/ coir micro-particles. SEM micrographs of CFTIPE composite observed at the fractured part represents disintegration, whereas the Innegra fabric-fly ash-TiC-epoxy bonding does not isolate in certain parts even after the damage, which signifies the higher adhesive load between them. Filler accumulation, Innegra fabric damage, debonding, and inadequate filler-polymer adhesion portion are also observed from SEM micrograph of CFTIPE tensile experimented sample (Fig. 4d) (Rao et al., 2021).

\subsubsection{Flexural properties}

The flexural stress-strain graphs are shown in Fig. 3 (c). The flexural experiment's outcome in Fig. 3 (d) shows that the incorporation of TiC or fly ash particles affected an increment in the flexural modulus and strength. The epoxy polymer resin reinforced with coir micro-particle, fly ash, and Innegra fiber shows the 
highest flexural strength showing $127.22 \%$ enhancement over the neat polymer. The fly ash filler possesses a greater specific surface area compared with the TiC nanoparticles. Thus, when comprised with the polymeric networks, the fly ash particles can produce stronger bonding, a flexural load can be shifted through these inorganic filler networks to other enslave. Even though one network damages under external force, others can still hold the laminate structures, and the whole sample is not intimidated. It can also be concluded from the outcome that TiC incorporation is considered in enhancing the modulus potentially because of around uniform fillers in the epoxy polymer that rigidly support the nearby Innegra fabric layers. The versatility of the inorganic filler in improving the flexural strength reduces beyond the crucial addition of fly ash because of the accumulation of inorganic fillers (Shivamurthy et al., 2013;

Taurozzi et al., 2012). This filler accumulation is affected by an increment of filler-filler interactions during the mechanical stirring process (Sudheer et al., 2013). The fillers accumulation would potentially increment polymer-filler interruption viscosity and affect bad wetting reaction between them (Sudheer et al., 2013). Hence, the lower enhancement in the flexural characteristics was endorsed for CFTIPE that signifies $65 \%$ improvement compared to a neat epoxy polymer. The CFIPE has a greater flexural modulus when compared with the CTIPE composite (Zhang et al., 2017; Chaurasia et al., 2019). Hence, the highest flexural modulus was endorsed for CTIPE composite that signifies $102.88 \%$ improvement compared to a pure epoxy polymer. The flexural modulus also enhanced TiC nanoparticles' report and the epoxy polymer physical networking (Chaurasia et al., 2019). Furthermore, CFTIPE and CIPE exhibited lower flexural modulus compared with CFIPE and CTIPE since the fillers accumulation may have considered, which reduced the reinforcement efficacy and decreased the efficient contact area within the polymer and filler particles (Rao et al., 2021).

\subsubsection{Interlaminar shear strength}

The general shear stress vs. strain variation is presented in Fig. 3 (e) is remarkably distinct for every laminate. From the curve, it can be concluded that the CIPE composite can withstand a force 1.98 times higher than the pure epoxy polymer, whereas CFIPE bears an influence of $28 \%$ larger than the pure polymer. Also, CFIPE shows a greater shear strength than pure epoxy polymer, as observed from Fig. 3 (e). Five specimens were experimented with in every combination for the calculation of shear strength value. The mean and standard errors of every combination have also been shown in Fig. 3 (f). The higher value of inter-laminar shear strength for CIPE composites is obtained due to the addition of Innegra fabric which improves the interlayer roughness of the surface compared with CFIPE, CTIPE, and CFTIPE composites. As the expansion of inorganic filler expands the crucial value, the epoxy resin network's movement may get harmed. This can influence bad-wetting with the fiber and potentially reduce the shear strength value (Rao et al., 2021). The resin networks around the surface of the particle are entirely dissimilar from the extent polymer.

\subsubsection{Impact strength and Hardness}

The impact strength of the epoxy polymer composites can be examined from Fig. 5. Compared with CFIPE or CTIPE composite, the impact strength of the CFTIPE composite was reduced. It has been already discussed in different kinds of literature that incorporating hybrid inorganic fillers in the polymer resin 
decrements their impact strength (Zhou et al., 2019; Zhang and Qi, 2014). A higher concentration of incorporating fillers was more significant than the decrement in the impact strength. Furthermore, reinforcing $\mathrm{TiC}$ or fly ash in the coir-Innegra fiber-epoxy composite enhanced the impact strength considerably for CFIPE and CTIPE specimens compared to CFTIPE by $7.52 \%$ and $18.4 \%$, respectively. This probable increment in the impact strength was because of the epoxy matrix's toughening with fly ash and TiC particles. Also, CTIPE exhibited a higher impact strength of $46.59 \mathrm{~kJ} / \mathrm{m}^{2}$, slightly higher than CFIPE. Hence, the positive influence of $\mathrm{TiC}$ nanoparticles addition on impact strength is apparent. The hybridization exhibited a possible effect on impact strength assignable to the enhanced interfacial adhesion and good toughening features transmitted by the appearance of TiC nanoparticles, coir microparticles, and Innegra fabric the epoxy matrix. Similarly, Khandelwal and Rhee (2020) also examined and expressed that inorganic filler influence on basalt fabric polymer laminate interface. Within the hybrid laminates, the effect of reducing filler concentration was more uttered than the incrementing filler to filler interactions (Satapathy and Kothapali, 2018).

The shore-D hardness of coir-Innegra fiber epoxy hybrid composites as presented in Fig. 5. The outcome shows that the reinforcement of fillers enhances the fabricated CIPE, CFIPE, CTIPE, and CFTIPE composites' hardness. As a result of the addition of retrieved filler, the enhancement of hardness was reported as high for CFTIPE laminate than the CIPE, CFIPE, and CTIPE laminate. Furthermore, a considerable enhancement in hardness was examined for CFTIPE laminates. Remarkably, the enhancement was up to $4 \%$ for the CFTIPE composite when compared with other combinations. The enhancement in the hardness of a laminate is based on the fly ash and TiC nanoparticles (Agarwal et al., 2014). The inter-particle void of the fillers in the epoxy polymer is considerably reduced with fly ash and $\mathrm{TiC}$ nanoparticles. This outcome in a higher quantity of load-bearing regions being obtained in the laminates. This conclusion was also reported in the glass fabric epoxy laminates reinforced with fired alumina (Sabarinathan et al., 2020).

\subsection{Thermal stability}

The synergy between fillers, Innegra fabric, and epoxy resin is investigated from DSC examination. To examine the glass transition temperature, DSC investigations are conducted with an optimum heating rate of $10^{\circ} \mathrm{C} / \mathrm{min}$. In Fig. 6 (a), heat flow with incrementing temperature in epoxy hybrid laminates is exhibited. The glass transition temperature of fabricated epoxy hybrid composites is estimated from the extrapolation of the endothermic peak. It is examined that the glass transition temperature measured from DSC curves is highest for CTIPE composite, and it entails the better interaction within the fillers, Innegra fabric, and epoxy matrix. The CFTIPE composite has observed a slight decrement with the addition of fly ash because of the lower stability of hydrogen bonding under elevated temperature (Lei et al., 2016; Wang et al., 2016).

The thermal stability curve of pure and different fillers and Innegra fabrics reinforced epoxy hybrid composites was examined from TGA and DTG (Fig. 6b, c). The enduring weight percentage of pure epoxy and their respective laminates as a function of temperature with the heating rate of $15^{\circ} \mathrm{C} / \mathrm{min}$ has been explained for different constituents' thermal stability examination. The epoxy hybrid composites that 
withstand under a higher temperature range at a given weight percentage are more thermally stable when compared with other combinations. The thermal characteristics of pure epoxy and their respective hybrid laminates were determined between the ranges of temperature $160-600^{\circ} \mathrm{C}$. This temperature range was considered due to the deviation of weight exhibited additional influence because of appreciable oxidation and water absorption after $600^{\circ} \mathrm{C}$ and before $160^{\circ} \mathrm{C}$ (Ogasawara et al., 2011). CFIPE epoxy hybrid laminate exhibited the highest thermal stability (onset and end-set temperature of 344.66 and $416.72^{\circ} \mathrm{C}$ ) compared with other laminates (Table 2). The initial weight loss of epoxy hybrid composites is critical to interpreting their thermal stability.

Furthermore, the epoxy resins have a comparably higher cross-linking focus which establishes comparably higher degradation temperature (Niu et al., 2014; Chatterjee and Islam, 2008). The improvement in thermal stability of CFIPE composite was because of the strong interaction of polymeric network, fillers, and Innegra fabrics. The reduction in thermal stability with TiC fillers in the polymer maybe because of the higher cluster size deviation of fillers in an epoxy polymer. The greater cluster size with non-homogeneous dispersion in the epoxy polymer may negatively impact the interfacial-bonding of filler-polymer and decreases the thermal stability of laminates. The carbon residue yield of epoxy hybrid composite is considerably enhanced in the CFIPE composite (Table 2). The endorsed carbon residue could be assigned to the further cross-linking within the polymer, Innegra fabric, and fillers (Ma et al., 2018).

Table 2

Thermal characteristics of coir fiber/ Innegra fiber/ TiC/ fly ash synthetic epoxy hybrid composites

\begin{tabular}{|lllll|}
\hline $\begin{array}{l}\text { Sample } \\
\text { designation }\end{array}$ & $\begin{array}{l}\text { Glass transition } \\
\text { temperature in }{ }^{\circ} \mathrm{C}\end{array}$ & $\begin{array}{l}\text { Onset } \\
\text { temperature in } \\
{ }^{\circ} \mathrm{C}\end{array}$ & $\begin{array}{l}\text { Endset } \\
\text { temperature in }{ }^{\circ} \mathrm{C}\end{array}$ & $\begin{array}{l}\text { Carbon } \\
\text { residue in \% }\end{array}$ \\
\hline PE & 77.21 & 334.04 & 403.67 & 7.32 \\
\hline CIPE & 171.17 & 336.46 & 405.85 & $10.93 \%$ \\
\hline CFIPE & 170.5 & 344.66 & 416.72 & $10.16 \%$ \\
\hline CTIPE & 177.33 & 338.84 & 410.83 & $8.63 \%$ \\
\hline CFTIPE & 176.17 & 344.26 & 412.23 & $8.79 \%$ \\
\hline
\end{tabular}

\section{Conclusion}

The developed epoxy hybrid composites were fabricated from the mechanical-stirring assisted wet layup method. Tensile, flexural, inter-laminar shear, impact strength, resistance from water absorption, glass transition temperature, and the epoxy hybrid composites' thermal stability were improved compared with neat epoxy polymer. The impact strength has the lowest and highest impact strength of $46.59 \mathrm{~kJ} / \mathrm{m} 2$ and $32.03 \mathrm{~kJ} / \mathrm{m} 2$ by CTIPE and CIPE composites. This signified a possible hybridization influence transmitted from the TiC nanoparticles on the epoxy polymer laminate. The previous characteristics of the hybrid 
laminates were examined to enhance the addition of fly ash and TiC fillers. Apart from all the laminate fabrication, hybrid laminate with TiC nanoparticles showed an enhancement of 10.88 times in the impact strength compared with epoxy polymer. The chosen optimum resin blend of epoxy, fly ash, TiC nanofillers, and Innegra fabrics as the polymer matrix indeed promoted this enhancement. The stronger interfacial adhesion of fly ash, TiC nanofiller, and Innegra fabrics with the epoxy matrix, as observed from the FTIR examination, permitted an efficient load transfer using the interphases. Even though there was a slight decrement in the tensile strength of the CFIPE composites compared to laminate possessing coir microparticles, fly ash, and Innegra fabrics alone, the flexural and tensile characteristics were in the proximity of the epoxy polymer. Apart from all the fabricated laminates, the lowest and highest strength of 66.09 $\mathrm{MPa}$ and $111.91 \mathrm{MPa}$ were reported from CFIPE and CIPE composite.

Additionally, a similar trend has been examined for tensile modulus, where the remarkable and lower tensile modulus of 1044.7 MPa and 731.71 MPa for CFTIPE and CIPE composite, respectively. The flexural characteristics of the laminates also pursued the same trend as tensile. The laminates flexural modulus and strength investigate exhibit that CFIPE occurs the maximum flexural modulus and strength as 153.01 MPa and 2556.3 MPa. The distribution of coir micro-particles, fly ash, TiC nanoparticles, and Innegra fabrics in the epoxy polymer were proved from SEM micrographs. CFIPE composite showed the most remarkable improvement in onset and end-set temperature up to $344.66^{\circ} \mathrm{C}$ and $416.72^{\circ} \mathrm{C}$, respectively. The glass transition temperature also exhibited the most significant improvement for CTISE composite around $100^{\circ} \mathrm{C}$ when compared with the pure epoxy polymer because of the better interactions between the fillers, Innegra fabric, and epoxy polymer. Cross-linking density and thermal stability of CFIPE, CTIPE, and CFTIPE composite also exhibited considerable improvement compared with pure epoxy polymer.

\section{Declarations}

Funding: Not applicable

Statement of ethical approval: Not applicable

Conflicts of interest: None

Informed consent: Not applicable

Ethical standards: Not applicable

\section{References}

1. Abdel-Gawad NMK, El Dein AZ, Mansour DEA, Ahmed HM, Darwish MMF, Lehtonen M (2018) Multiple enhancement of PVC cable insulation using functionalized SiO 2 nanoparticles based nanocomposites. Electr Power Syst Res 163:612-625. https://doi.org/10.1016/j.epsr.2017.11.011 
2. Agarwal G, Patnaik A, Sharma RK (2014) Thermo-Mechanical Properties and Abrasive Wear Behavior of Silicon Carbide Filled Woven Glass Fiber Composites. Silicon 6:155https://doi.org/10.1007/s12633-014-9184-4

3. Ajdary R, Tardy BL, Mattos BD, Bai L, Rojas OJ (2020) Plant Nanomaterials and Inspiration from Nature: Water Interactions and Hierarchically Structured Hydrogels. Adv Mater 2001085. https://doi.org/10.1002/adma.202001085

4. AsI SMH, Ghadi A, Baei MS, Javadian H, Maghsudi M, Kazemian H (2018) Porous catalysts fabricated from coal fly ash as cost-effective alternatives for industrial applications: A review. Fuel 217:320-342. https://doi.org/10.1016/j.coal.2017.05.007

5. Asl SMH, Javadian H, Khavarpour M, Belviso C, Taghavi M, Maghsudi M (2019) Porous catalysts fabricated from coal fly ash as cost-effective alternatives for industrial applications: A review. J Clean Prod 208:1131-1147. https://doi.org/10.1016/j.fuel.2017.12.111

6. Bal S (2010) Experimental study of mechanical and electrical properties of carbon nanofiber/epoxy composites. Mater Des 31(5):2406-2413. https://doi.org/10.1016/j.matdes.2009.11.058

7. Becker C, Krug H, Schmidt H (1996) Tailoring of Thermomechanical Properties of Thermoplastic Nanocomposites by Surface Modification of Nanoscale Silica Particles. MRS Proc. 435:237. https://doi.org/10.1557/proc-435-237

8. Cai J, Pan J, Li X, Tan J, Li J (2020) Electrical resistivity of fly ash and metakaolin based geopolymers. Construct Build Mater 234:117868. https://doi.org/10.1016/j.conbuildmat.2019.117868

9. Chatterjee A, Islam MS (2008) Fabrication and characterization of TiO2-epoxy nanocomposite. Mater Sci Eng A 487(1-2)574-585. https://doi.org/10.1016/j.msea.2007.11.052

10. Chaurasia A, Verma A, Parashar A, Mulik RS (2019) Experimental and Computational Studies to Analyze the Effect of h-BN Nanosheets on Mechanical Behavior of h-BN/Polyethylene Nanocomposites. J Phys Chem C 123:20059-20070. https://doi.org/10.1021/acs.jpcc.9b05965

11. Civancik-Uslu D, Ferrer L, Puig R, Fullana-I-Palmer P (2018) Are functional fillers improving environmental behavior of plastics? A review on LCA studies. Sci Total Environ 626:927-940. https://doi.org/10.1016/j.scitotenv.2018.01.149

12. Cui JY, Cai YB, Yuan WJ, Lv ZF, Zhang C, Xu SA (2017) Preparation of PMMA grafted calcium carbonate whiskers and its reinforcement effect in PVC. Polym Compos 38:2753-2761. https://doi.org/10.1002/pc.23873

13. Dahalan ENE, Sofian AH, Abdullah A, Noor NM (2018) Corrosion behavior of organic epoxy-xinc coating with fly ash as an extender pigment. Mater Today 5:21629-21635. https://doi.org/10.1016/j.matpr.2018.07.012

14. Deshmukh AR, Aloui HA, Khomlaem C, Negi A, Yun JH, Kim HS (2021) Biodegradable films based on chitosan and defatted Chlorella biomass: Functional and physical characterization. Food Chem 337:127777. https://doi.org/10.1016/j.foodchem.2020.127777 
15. Ding J, Ma SH, Shen S, Xie ZL, Zheng SL, Zhang Y (2017) Research and industrialization progress of recovering alumina from fly ash: A concise review. Waste Manag. 60:375-387.

https://doi.org/10.1016/j.wasman.2016.06.009

16. Duraibabu D, Alagar M, Kumar SA (2014) Studies on mechanical, thermal and dynamic mechanical properties of functionalized nanoalumina reinforced sulphone ether linked tetraglycidyl epoxy nanocomposites. RSC Adv 4(76):40132-40140. https://doi.org/10.1039/c4ra06511e

17. Eskin $\mathrm{GI}$ (2001) Broad prospects for commercial application of the ultrasonic (cavitation) melt treatment of light alloys. Ultrason Sonochem 8(3):319-325. https://doi.org/10.1016/s13504177(00)00074-2

18. Finch A (1970) Chemical Applications of Far Infrared Spectroscopy, Academic Press, New York.

19. Halder S, Ghosh PK, Goyat MS (2012) Influence of ultrasonic dual mode mixing on morphology and mechanical properties of ZrO2-epoxy nanocomposite. High Perform Polym 24(4):331-341. https://doi.org/10.1177/0954008312440714

20. Halder S, Ghosh PK, Goyat MS, Ray S (2012) Ultrasonic dual mode mixing and its effect on tensile properties of SiO2-epoxy nanocomposite. J Adhes Sci Technol 27(2):111-124. https://doi.org/10.1080/01694243.2012.701510

21. Hower JC, Groppo JG, Graham UM, Ward CR, Kostova IJ, Maroto-Valer MM, Dai S (2017) Coal-derived unburned carbons in fly ash: A review. J Coal Geol 179:11-27. https://doi.org/10.1016/j.earscirev.2014.11.016

22. Imai T, Sawa F, Nakano T, Ozaki T, Shimizu T, Kozako M, Tanaka T (2006) Effects of nano- and microfiller mixture on electrical insulation properties of epoxy based composites. IEEE Trans Dielectr Electr Insul 13(2):319-326. https://doi.org/10.1109/tdei.2006.1624276

23. Jena DK, Sahoo PK (2019) New strategies for the construction of eggshell powder reinforced starch based fire hazard suppression biomaterials with tailorable thermal, mechanical and oxygen barrier properties. Int J Biol Macromol 140:496-504. https://doi.org/10.1016/j.ijbiomac.2019.08.156

24. Ji M, Li F, Li J, Zhang C, Sun K, Guo K (2021) Enhanced mechanical properties, water resistance, thermal stability, and biodegradation of the starch-sisal fibre composites with various fillers. Mater Des 198:109373. https://doi.org/10.1016/j.matdes.2020.109373

25. Kang S, Hong SI, Choe CR, Park M, Rim S, Kim J (2001) Preparation and characterization of epoxy composites filled with functionalized nanosilica particles obtained via sol-gel process. Polym 42(3):879-887. https://doi.org/10.1016/s0032-3861(00)00392-x

26. Khaleghi M, Didehban K, Shabanian M (2017) Effect of new melamine-terephthaldehyde resin modified graphene oxide on thermal and mechanical properties of PVC. Polym Test 63:382-391. https://doi.org/10.1016/j.polymertesting.2017.08.018

27. Khandelwal S, Rhee RY (2020) Recent advances in basalt-fiber-reinforced composites: Tailoring the fiber-matrix interface. Compos Part B Eng 192:108011. https://doi.org/10.1016/j.compositesb.2020.108011 
28. Kumar A, Anant R, Kumar K, Chauhan SS, Kumar S, Kumar R (2016) Anticorrosive and electromagnetic shielding response of a graphene/TiO2-epoxy nanocomposite with enhanced mechanical properties. RSC Adv 6(114):113405-113414. https://doi.org/10.1039/c6ra15273b

29. Kumar K, Ghosh PK, Kumar A, Singh O (2021) Enhanced Thermomechanical Properties of ZrO2 Particle Reinforced Epoxy Nanocomposite. J Mater Eng Perform 30(1):145-153. https://doi.org/10.1007/s11665-020-05350-3

30. Kumar K, Kumar S, Kumar A, Anant R, Kumar R (2017) Viscoelastic and thermally stable PDMS-SiO2 filled epoxy adhesive joint on steel substrate. Polym Compos 39:2889-2896. https://doi.org/10.1002/pc.24285

31. Lei L, Shan J, Hu J, Liu X, Zhao J, Tong Z (2016) Co-curing effect of imidazole grafting graphene oxide synthesized by one-pot method to reinforce epoxy nanocomposites. Compos Sci Technol 128:161-168. https://doi.org/10.1016/j.compscitech.2016.03.029

32. Li BH, Deng ZY, Wang WX, Fang HS, Zhou HB, Deng FX, Huang L, Li HY (2017) Degradation characteristics of dioxin in the fly ash by washing and ball-milling treatment. J Hazard Mater 339:191-199. https://doi.org/10.1016/j.jhazmat.2017.06.008

33. Liu P, Zhong W (2014) Novel magnetic crosslinked composites with fly ash as filler via facile "onepot" in-situ radical bulk polymerization. J Taiwan Inst Chem Eng 45:1098-1104. https://doi.org/10.1016/j.jtice.2013.09.029

34. Ma X, Peng C, Zhou D, Wu Z, Li S, Wang J, Sun N (2018) Synthesis and mechanical properties of the epoxy resin composites filled with sol-gel derived ZrO2 nanoparticles. J Sol-Gel Sci Technol 88(2):442-453. https://doi.org/10.1007/s10971-018-4827-3

35. Mallakpour S, Khadem E (2015) Recent development in the synthesis of polymer nanocomposites based on nano-alumina. Prog Polym Sci 51:74-93. https://doi.org/10.1016/j.progpolymsci.2015.07.004

36. May CA, Tanaka Y (1973) Epoxy Resin: Chemistry and Technology, Marcel Dekker, New York.

37. Mc Adams LV, Gannon JA (1986) Encyclopedia of Polymer Science and Engineering, WileyInterscience, New York.

38. Mohit H, Sanjay MR, Siengchin S, Khan A, Marwani HM, Dzudzevic-cancar H, Asiri AM (2021) Effect of TiC Nanoparticles Reinforcement in Coir Fiber Based Bio/Synthetic Epoxy Hybrid Composites: Mechanical and Thermal Characteristics. J Polym Environ 1-21. https://doi.org/10.1007/s10924021-02069-7

39. Niu Y, Zheng S, Song P, Zhang X, Wang C (2021) Mechanical and thermal properties of PEEK composites by incorporating inorganic particles modified phosphates. Compos Part B Eng 212:108715. https://doi.org/10.1016/j.compositesb.2021.108715

40. Niu YA, Zhang X, Tian YQ, Zhao JP, Yan XQ, Li Y (2014) Fabrication, structure and mechanism of reduced graphene oxide-based carbon composite films. J Mater Chem 2:10502. https://doi.org/10.1039/c4ta00921e 
41. Nogueira P, Ramirez C, Torres A, Abad MJ, Cano J, Lopez J, Lopez-Bueno I, Barai L (2001) Effect of water sorption on the structure and mechanical properties of an epoxy resin system. J Appl Polym Sci 80(1):71-80. https://doi.org/10.1002/1097-4628(20010404)80:1<71::aid-app1077>3.0.co;2-h

42. Ogasawara T, Moon SY, Inoue Y, Shimamura Y (2011) Mechanical properties of aligned multi-walled carbon nanotube/epoxy composites processed using a hot-melt prepreg method. Compos Sci Technol 71(16):1826-1833. https://doi.org/10.1016/j.compscitech.2011.08.009

43. Omrani A, Simon LC, Rostami AA (2009) The effects of alumina nanoparticle on the properties of an epoxy resin system. Mater Chem Phys 114:145-150. https://doi.org/10.1016/j.matchemphys.2008.08.090

44. Patil AG, Mahendran A, Anandhan A (2016) Nanostructured Fly Ash as Reinforcement in a Plastomer-Based Composite: A New Strategy in Value Addition to Thermal Power Station Fly Ash. Silicon 8:159-173. https://doi.org/10.1007/s12633-014-9194-2

45. Pitarresi G, Toscano A, Alessi S (2018) Fracture toughness of synthesised high-performance epoxies subject to accelerated water aging. Polym Test 68:248-260. https://doi.org/10.1016/j.polymertesting.2018.04.010

46. Radoman TS, Dž unuzovic'JV, Jeremic' KB, Grgur BN, Milic`evic' DS, Popovic' IG, Dz unuzovic'ES (2014) Improvement of epoxy resin properties by incorporation of TiO2 nanoparticles surface modified with gallic acid esters. Mater Des 62:158-167. https://doi.org/10.1016/j.matdes.2014.05.015

47. Ramanujam S, Desai ABM, Mishra P, Vasa N, Imai T (2019) Understanding the performance of gamma-ray-irradiated epoxy nanocomposites. Micro Nano Lett 14(1):107-112. https://doi.org/10.1049/mnl.2018.5402

48. Rao YS, Mohan NS, Shetty N, Shivamurthy B (2021) Effects of solid lubricant fillers on the flexural and shear strength response of carbon fabric-epoxy composites. Polym Test 96:107085. https://doi.org/10.1016/j.polymertesting.2021.107085

49. Rong MZ, Zhang MQ, Liu H, Zeng H, Wetzel B, Friedrich $\mathrm{K}$ (2001) Microstructure and tribological behavior of polymeric nanocomposites. Ind Lubr Tribol 53(1):72-77. https://doi.org/10.1108/00368790110383993

50. Rs B (1979) Epoxy Resin Chemistry, Advances in Chemistry. American Chemical Society, Washington, DC.

51. Sabarinathan P, Annamalai VE, Rajkumar K (2020) Optimization of Process Parameter in Abrasive Water Jet Machining of Blue-Fired Grain-Reinforced Glass Fiber Polymer Composite. Trends Manuf Eng Manag 217-226. https://doi.org/10.1007/978-981-15-4745-4_20

52. Satapathy S, Kothapalli RVS (2018) Mechanical, Dynamic Mechanical and Thermal Properties of Banana Fiber/Recycled High Density Polyethylene Biocomposites Filled with Flyash Cenospheres. J Polym Environ 26:200-213. https://doi.org/10.1007/s10924-017-0938-0

53. Shivamurthy B, Bhat KU, Anandhan S (2013) Mechanical and sliding wear properties of multi-layered laminates from glass fabric/graphite/epoxy composites. Mater Des 44:136-143. 
https://doi.org/10.1016/j.matdes.2012.07.059

54. Sudheer M, Madhyastha NK, Amanna MK, Jonthan B, Jayaprakash KM (2013) Mechanical and Abrasive Wear Behavior of Metal Sulphide Lubricant Filled Epoxy Composites. ISRN Polym Sci 242450:1-8. https://doi.org/10.1155/2013/242450

55. Sun T, Fan H, Wang Z, Liu X, Wu Z (2015) Modified nano Fe2O3-epoxy composite with enhanced mechanical properties. Mater Des 87:10-16. https://doi.org/10.1016/j.matdes.2015.07.177

56. Sun X, Jia XJ, Li FY, Li JF, Zhang SG (2019) Effect of poly-methyltriethoxysilane on the waterproof property of starch/fiber composites with open cell structures. RSC Adv 9(34):19508-19517. https://doi.org/10.1039/c9ra03221e

57. Sundum T, Szécsényi KM, Kaewtatip K (2018) Preparation and characterization of thermoplastic starch composites with fly ash modified by planetary ball milling. Carbohydr Polym 191:198-204. https://doi.org/10.1016/j.carbpol.2018.03.009

58. Taurozzi JS, Hackley VA, Wiesner MR (2012) Preparation of Nanoparticle Dispersions from Powdered Material Using Ultrasonic Disruption, NIST - Spec. Publ. https://doi.org/10.6028/nist.sp.1200-2

59. Temuujin J, Surenjav E, Ruescher $\mathrm{CH}$, Vahlbruch J (2019) Processing and uses of fly ash addressing radioactivity (critical review). Chemosph 216:866-882.

https://doi.org/10.1016/j.chemosphere.2018.10.112

60. Thongsang S, Vorakhan W, Wimolmala E, Sombatsompop N (2012) Dynamic mechanical analysis and tribological properties of NR vulcanizates with fly ash/precipitated silica hybrid filler. Tribol Int 53:134-141. https://doi.org/10.1016/j.triboint.2012.04.006

61. Tsekmes IA, Morshuis PHF, Smit JJ, Kochelov R (2015) Enhancing the thermal and electrical performance of epoxy microcomposites with the addition of nanofillers. IEEE Electr Insul Mag 31(3):32-42. https://doi.org/10.1109/mei.2015.7089120

62. Van der Merwe EM, Mathebula CL, Prinsloo LC (2014) Characterization of the surface and physical properties of South African coal fly ash modified by sodium lauryl sulphate (SLS) for applications in PVC composites. Powder Technol 266:70-78. https://doi.org/10.1016/j.powtec.2014.06.008

63. Wang CC, Zhao YY, Ge HY, Qian RS (2016) Enhanced mechanical and thermal properties of short carbon fiber reinforced polypropylene composites by graphene oxide. Polym Compos 39:405-413. https://doi.org/10.1002/pc.23950

64. Wang L, Wang K, Chen L, He C, Zhang Y (2006) Hydrothermal effects on the thermomechanical properties of high performance epoxy/clay nanocomposites. Polym Eng Sci 46(2):215-221. https://doi.org/10.1002/pen.20453

65. Wang Q, Xia H, Zhang C (2001) Preparation of polymer/inorganic nanoparticles composites through ultrasonic irradiation. J Appl Polym Sci 80(9):1478-1488. https://doi.org/10.1002/app.1239

66. Wang S, Zhang C, Chen J (2014) Utilization of Coal Fly Ash for the Production of Glass-ceramics With Unique Performances: A Brief Review. J Mater Sci Technol 30:1208-1212. https://doi.org/10.1016/j.jmst.2014.10.005 
67. Wu H, Xiao D, Lu J, Li T, Zhang Z (2020) Preparation and Properties of Biocomposite Films Based on Poly(vinyl alcohol) Incorporated with Eggshell Powder as a Biological Filler. J Polym Environ 28(7):2020-2028. https://doi.org/10.1007/s10924-020-01747-2

68. Wu PF, Cai ZW, Jin HB, Tang YY (2019) Adsorption mechanisms of five bisphenol analogues on PVC microplastics. Sci Total Environ 650:671-678. https://doi.org/10.1016/j.scitotenv.2018.09.049

69. Xia H, Wang Q (2003) Preparation of conductive polyaniline/nanosilica particle composites through ultrasonic irradiation. J Appl Polym Sci 87(11):1811-1817. https://doi.org/10.1002/app.11627

70. Xu LR, Bhamidipati V, Zhong WH, Li J, Lukehart CM, Lara-Curzio E, Liu KC, Lance MJ (2004) Mechanical Property Characterization of Polymeric Nanocomposite Reinforced by Graphitic Nanofibers with Reactive Linkers. J Compos Mater 38(18):1563-1582. 10.1177/0021998304043758

71. Yao ZT, Ji XS, Sarker PK, Tang JH, Ge LQ, Xia MS, Xi YQ (2015) A comprehensive review on the applications of coal fly ash. Earth Sci Rev 141:105-121. https://doi.org/10.1016/j.earscirev.2014.11.016

72. Yuan S, Shen F, Chua CK, Zhou K (2019) Polymeric composites for powder-based additive manufacturing: Materials and applications. Prog Polym Sci 90:141-168. https://doi.org/10.1016/j.progpolymsci.2018.11.001

73. Yuan WJ, Cui JY, Xu SA (2016) Mechanical Properties and Interfacial Interaction of Modified Calcium Sulfate Whisker/Poly(Vinyl Chloride) Composites. J Mater Sci Technol 32:1352-1360. https://doi.org/10.1016/j.jmst.2016.05.016

74. Zhang CW, Li FY, Li JF, Li YL, Xu J, Xie Q (2018) Novel treatments for compatibility of plant fiber and starch by forming new hydrogen bonds. J Clean Prod 185:357-365. https://doi.org/10.1016/j.jclepro.2018.03.001

75. Zhang CW, Li FY, Li JF, Wang LM, Xie Q, Xu J, Chen S (2017) A new biodegradable composite with open cell by combining modified starch and plant fibers. Mater. Des. 120:222-229. https://doi.org/10.1016/j.matdes.2017.02.027

76. Zhang J, Qi S (2014) Mechanical, thermal, and dielectric properties of aluminum nitride/glass fiber/epoxy resin composites. Polym Compos 35:381-385. https://doi.org/10.1002/pc.22671

77. Zhang K, Feng Y, Wang F, Yang Z, Wang J (2017) Two dimensional hexagonal boron nitride (2DhBN): synthesis, properties and applications. J Mater Chem C 5:11992-12022. https://doi.org/10.1039/c7tc04300g

78. Zhou Q, Wen J, Wu J, Ma W, Xu M, Wei K, Xu J (2019) Recovery and purification of metallic silicon from waste silicon slag in electromagnetic induction furnace by slag refining method. $J$ Clean Prod 229:1335-1341. https://doi.org/10.1016/j.jclepro.2019.05.071

79. Zou C, Fothergill JC, Rowe SW (2008) The effect of water absorption on the dielectric properties of epoxy nanocomposites. IEEE Trans Dielectr Electr Insul 15(1):106-117. https://doi.org/10.1109/tdei.2008.4446741

80. Zunjarrao SC, Singh RP (2006) Characterization of the fracture behavior of epoxy reinforced with nanometer and micrometer sized aluminum particles. Compos Sci Technol 66(13):2296-2305. 


\section{Figures}

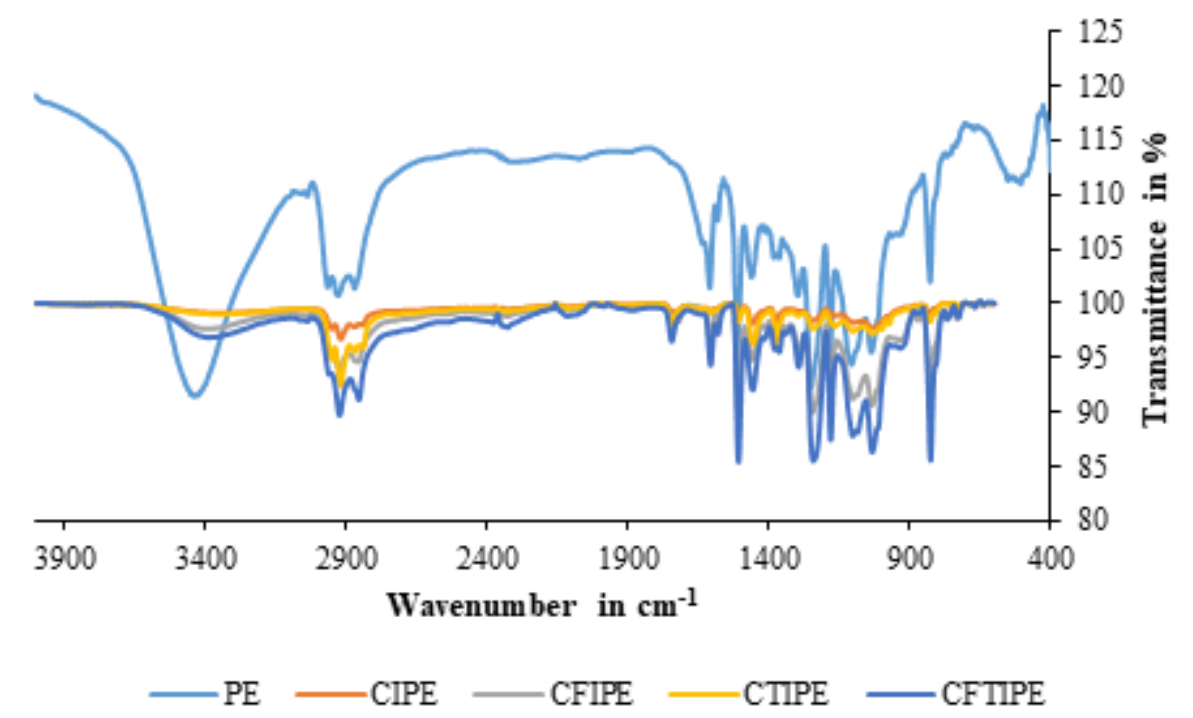

Figure 1

FTIR Spectra of coir fiber/ Innegra fiber/ TiC/ fly ash synthetic epoxy hybrid composites 


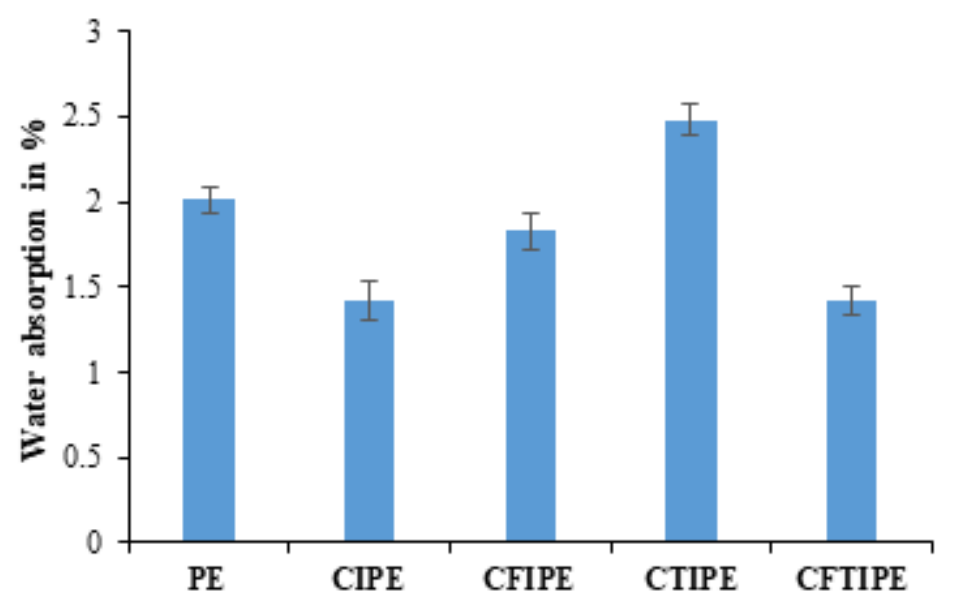

(a)

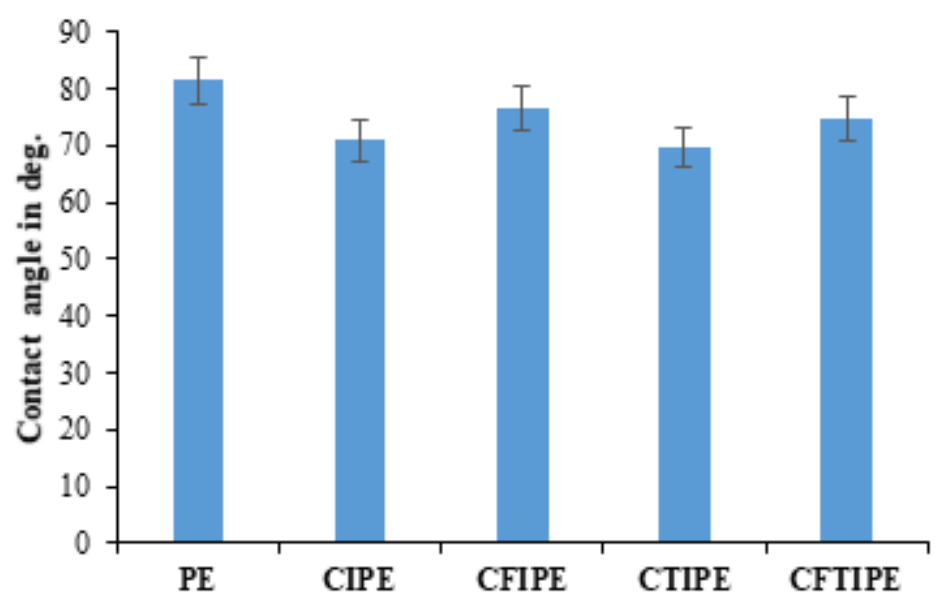

(b)

Figure 2

Physical properties of coir fiber/ Innegra fiber/ TiC/ fly ash synthetic epoxy hybrid composites (a) water absorption, and (b) Contact angle 


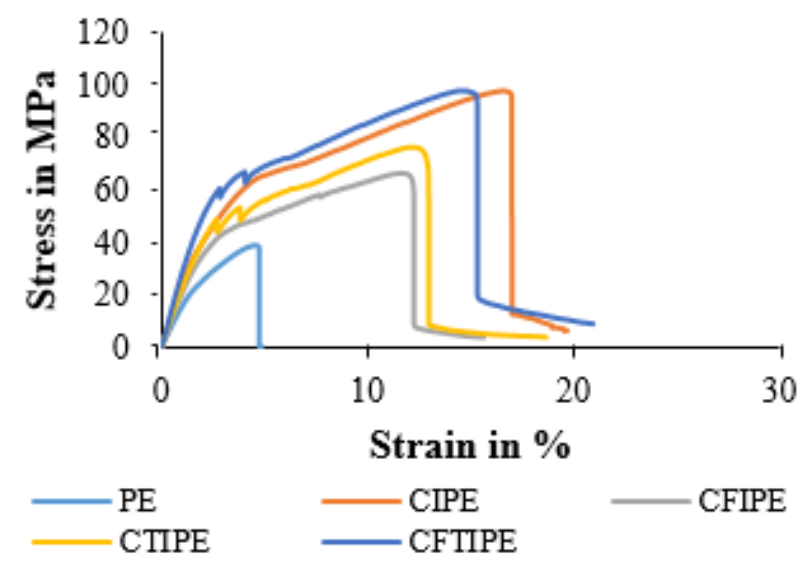

(a)

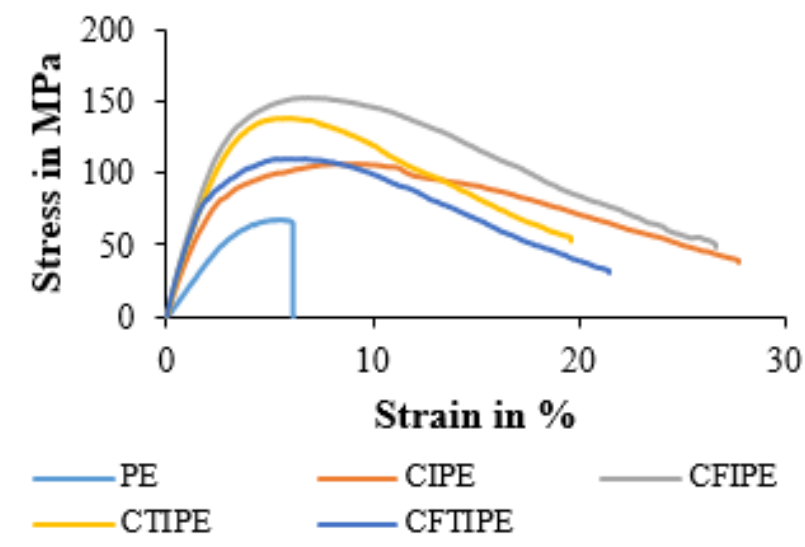

(c)

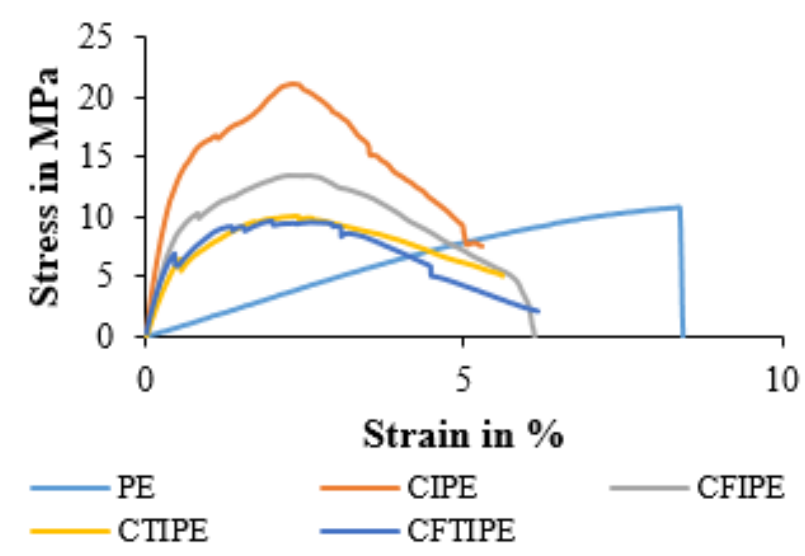

(e)

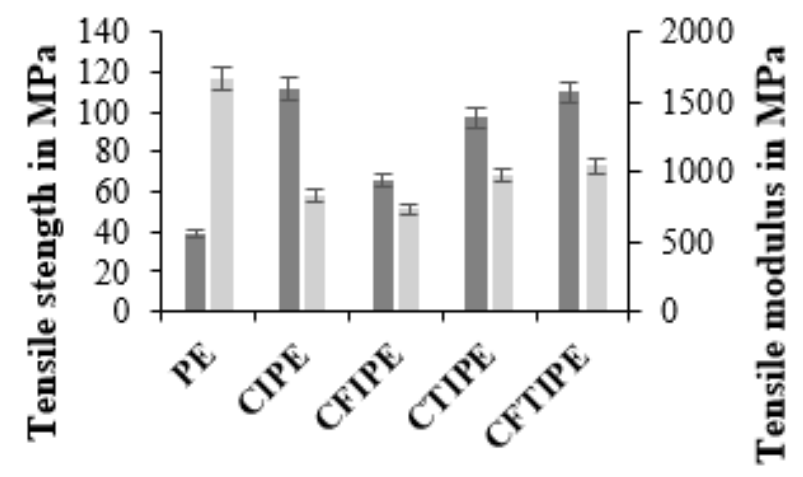

- Tensile strength $=$ Tensile modulus

(b)

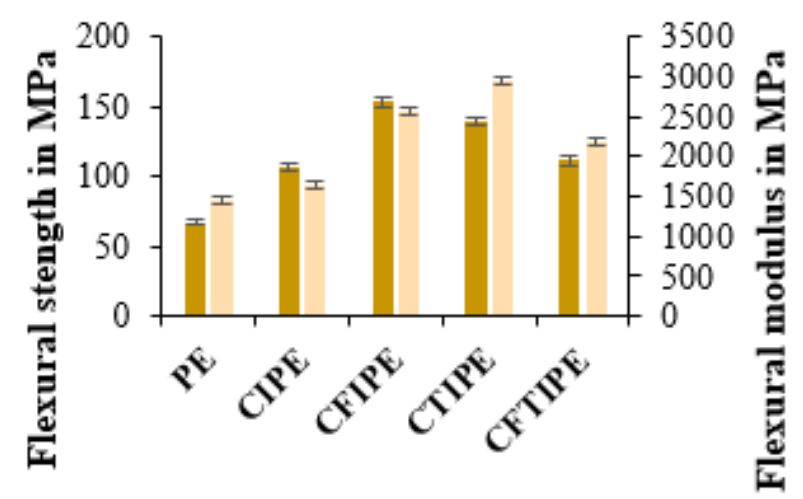

- Flexural strength $\quad$ Flexural modulus

(d)

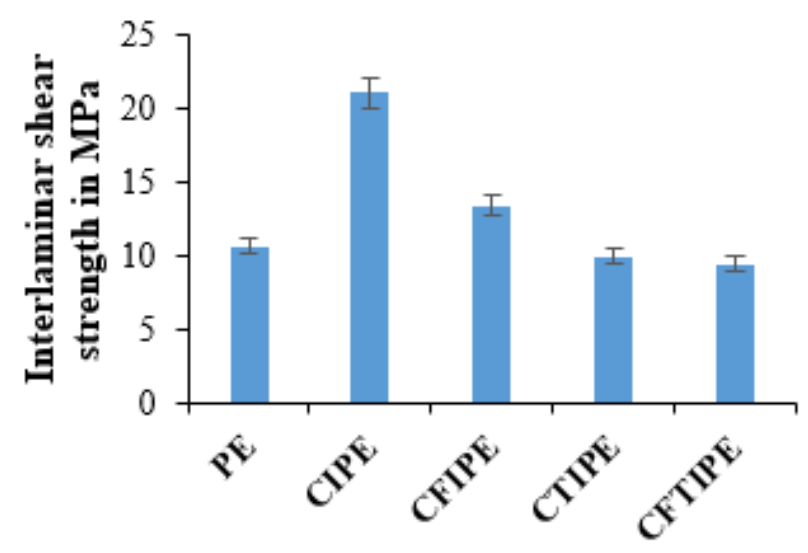

(f)

\section{Figure 3}

Mechanical properties of coir fiber/ Innegra fiber/ TiC/ fly ash synthetic epoxy hybrid composites (a) Tensile stress-strain, (b) tensile properties, (c) Flexural stress-strain, (d) flexural properties, (e) ILSS stressstrain, and (f) ILSS 


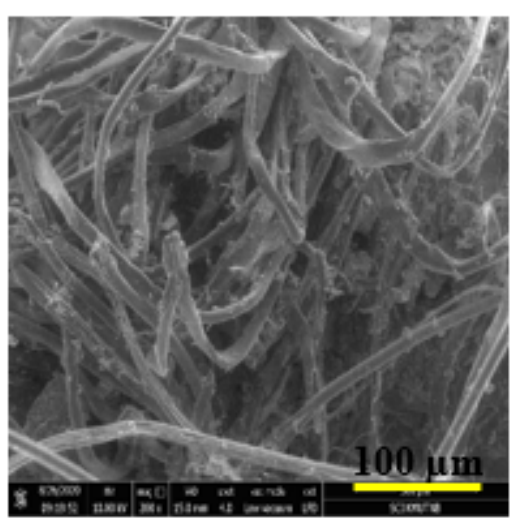

(a)

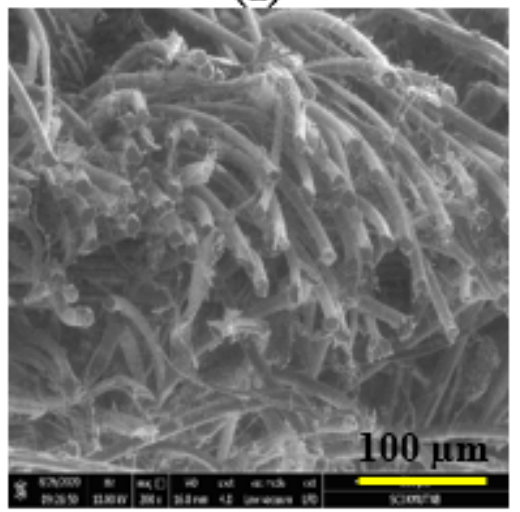

(c)

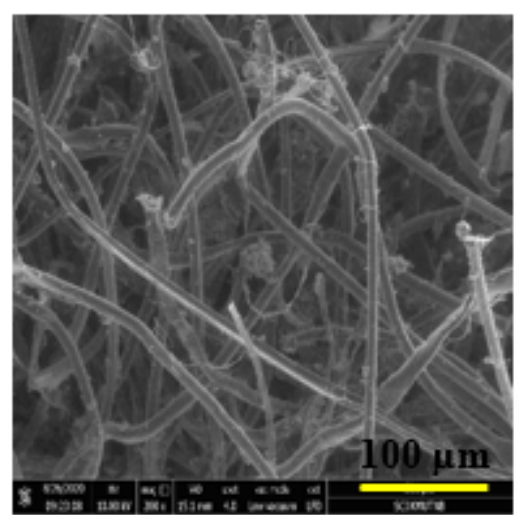

(b)

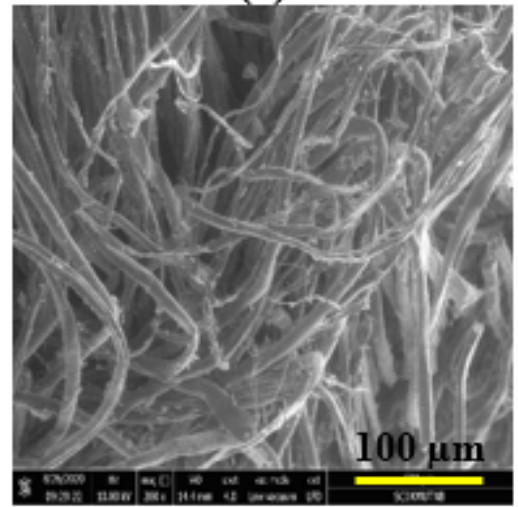

(d)

Figure 4

Tensile fracture of coir fiber/ Innegra fiber/ TiC/ fly ash synthetic epoxy hybrid composites (a) PE, (b) CIPE, (c) CFIPE, (d) CTIPE, and (e) CFTIPE

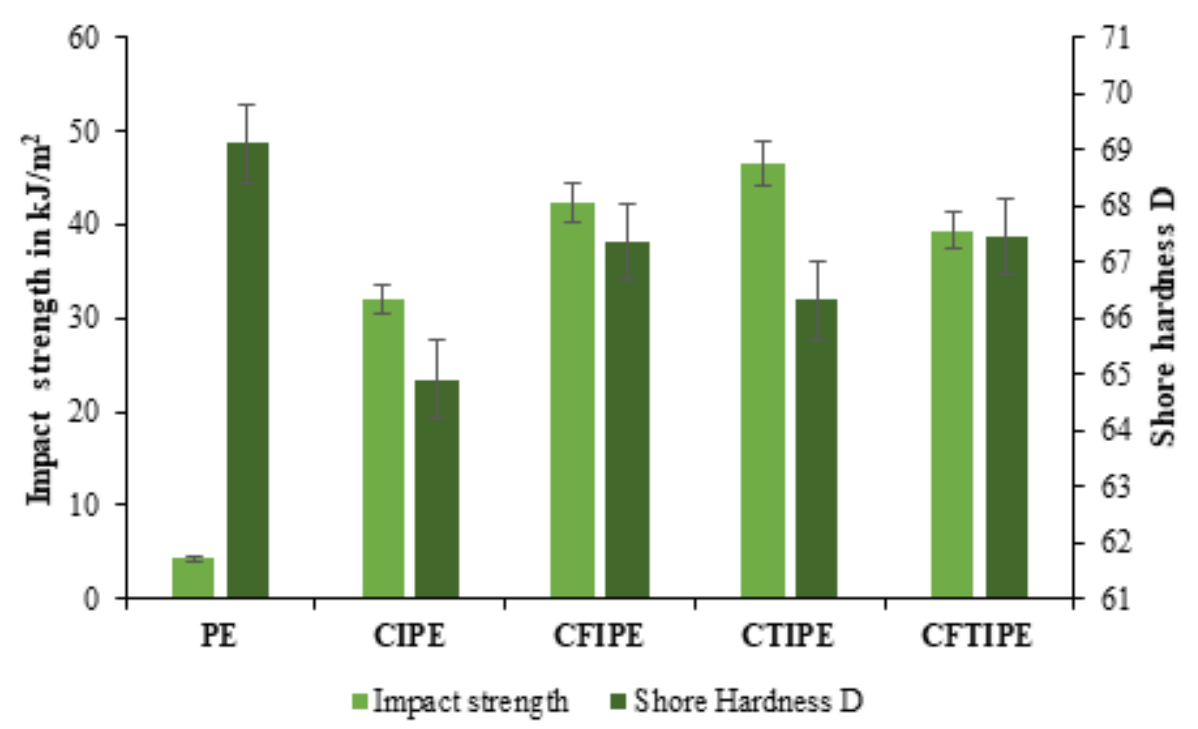

Figure 5

Impact strength and shore hardness of coir fiber/ Innegra fiber/ TiC/ fly ash synthetic epoxy hybrid composites 


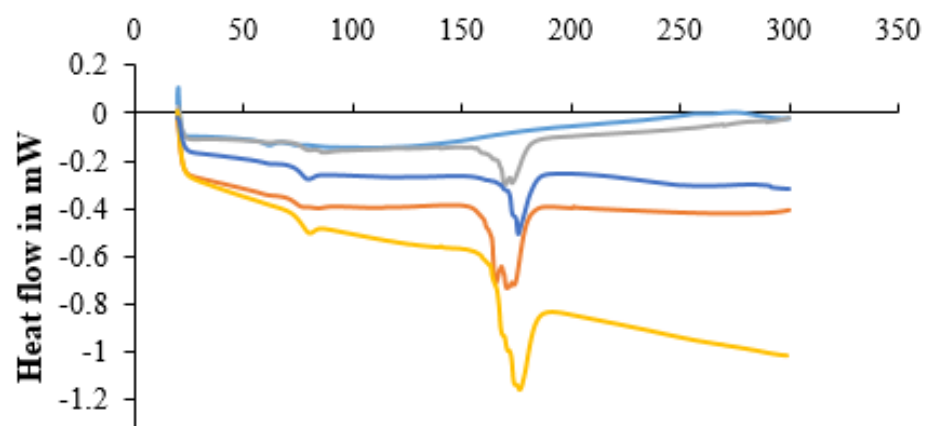

Sample temperature in ${ }^{\circ} \mathrm{C}$

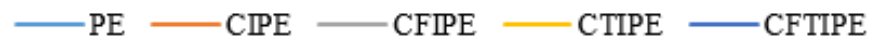

(a)

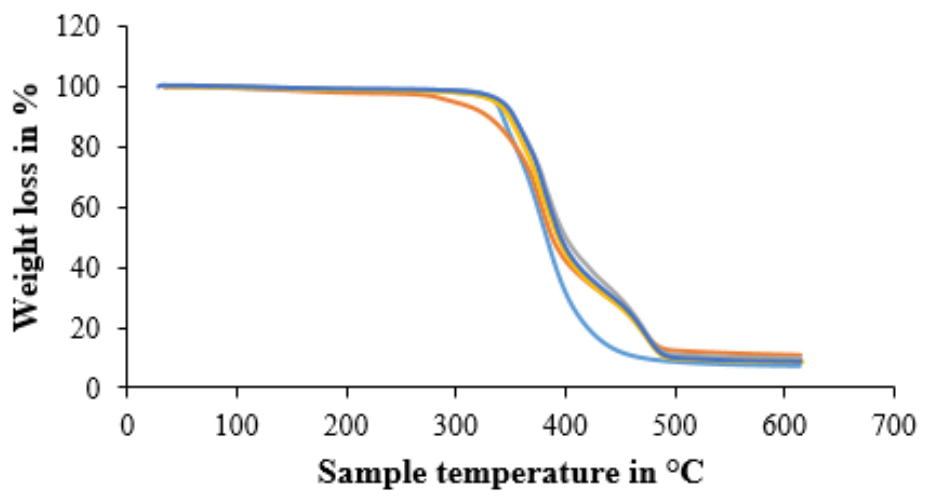

$-\mathrm{PE} \longrightarrow \mathrm{CIPE} \longrightarrow \mathrm{CFPE} \longrightarrow \mathrm{CTIPE} \longrightarrow \mathrm{CFTIPE}$

(b)

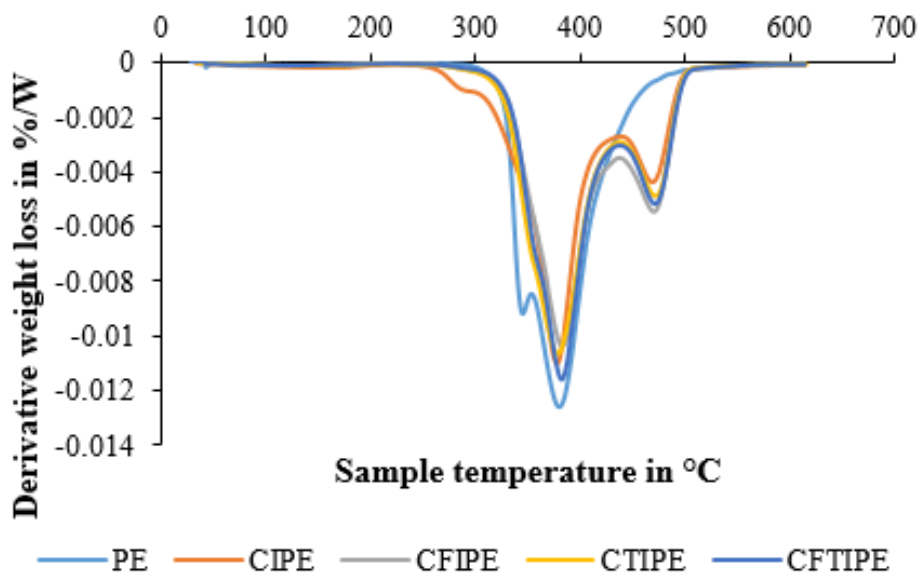

(c)

\section{Figure 6}

Thermal characteristics of coir fiber/ Innegra fiber/ TiC/ fly ash synthetic epoxy hybrid composites (a) DSC, (b) TGA, and (c) DTG curves 